\title{
PHYTOCHEMICAL SCREENING, ELEMENTAL AND FUNCTIONAL GROUP ANALYSIS OF VITEX NEGUNDO L. LEAVES
}

\author{
SUNIL PAWAR, VANITA KAMBLE* \\ Department of Botany, Yashwantrao Mohite College of Arts, Science and Commerce, Pune, Bharati Vidyapeeth Deemed University, \\ Maharashtra, (India) 411038 \\ Email: kamblevanita25@gmail.com
}

Received: 22 Feb 2017 Revised and Accepted: 29 Apr 2017

\section{ABSTRACT}

Objective: To analyse elemental profile, evaluate functional groups and find out phytochemical constituents of Vitex negundo L. leaves.

Methods: Determination of primary and secondary metabolites for various extracts by qualitative methods. Elemental analysis was carried out by using inductively coupled plasma mass spectrometry (ICP-MS) technique and the functional groups have been determined by using Fourier Transform Infrared Spectroscopy (FTIR) technique.

Results: Soluble extractive percentage of material has been found the maximum in the aqueous extract (6.75\%) followed by methanolic extract (4.35\%) and acetone extract (1.8\%). Phytochemical screening of material revealed the presence of carbohydrates, proteins, amino acids, steroids, cardiac and anthraquinone glycosides, saponins, flavonoids, tannins and phenolic compounds. The elemental analysis revealed $\mathrm{Na}, \mathrm{Mg}$, $\mathrm{K}$, $\mathrm{Ca}$, $\mathrm{Cr}$, $\mathrm{Mn}, \mathrm{Fe}, \mathrm{Co}, \mathrm{Cu}, \mathrm{Zn}$, $\mathrm{Se}, \mathrm{Mo}, \mathrm{Li}, \mathrm{B}, \mathrm{Al}, \mathrm{P}, \mathrm{Cd}, \mathrm{As}, \mathrm{Ba}$, and Hg. FTIR technique was used to identify various functional groups present in three different extracts of the material.

Conclusion: The phytochemical screening of three different extracts of the material showed the presence of most of the primary and secondary metabolites in aqueous and methanolic extract than acetone extract. The soluble extractive value was found the maximum in aqueous extract hence aqueous extract is most effective for studying the pharmacological activity of this plant. Elemental analysis showed the presence of trace elements in sufficient concentrations and traces of heavy and toxic metals. The FTIR study revealed the presence of essential functional groups in three different extracts of the material. The present investigation is most essential to discover innovative, dynamic and novel drugs for curing various newly emerged dangerous health problems.

Keywords: Phytochemical screening, Elemental analysis, FTIR, ICP-MS, Secondary metabolites

(C) 2017 The Authors. Published by Innovare Academic Sciences Pvt Ltd. This is an open access article under the CC BY license (http://creativecommons.org/licenses/by/4.0/) DOI: http://dx.doi.org/10.22159/ijpps.2017v9i6.18093

\section{INTRODUCTION}

Herbal medicine is as old as a human race and is being used for the primary health care of human being since ancient period. Traditional medicinal plants contain therapeutic active substances, which is a precursor for the synthesis of herbal drugs [1]. Important drugs have been derived from plant resources directly or indirectly. Phytochemicals such as alkaloids, flavonoids, phenolic compounds, glycosides etc. play a significant role in pharmacological properties of plants. Screening of phytochemicals gives an idea about medicinal properties and values of plants. Vitex negundo L. belongs to the family Verbenaceae. It is woody, aromatic shrub, commonly known as nirgudi in Marathi and five-leaved chaste tree in English. In Ayurveda, it is used as antihelmentic and in folklore system, it is used in the treatment of asthma, cancer, jaundice, liver disorders, wounds, rheumatism, joint pains, antiallergic agent etc [2]. Extract of nirgudi has been shown various biological activities such as antibacterial [3], antifeedant [4], antifungal [5], antilarval [6], insecticidal [7], pesticidal activity [8], analgesic activity [9], anti-inflammatory activity [10, 11], anticonvulsant activity [12], antioxidant activity [13,14] etc. Almost all parts of nirgudi like leaves, roots, bark, fruits, flowers and seeds are used for medicinal purpose in the form of powder decoction, juice, oil, dry extract etc [15]. Vitex negundo used as folk medicine in most of the states of India.

Phytochemical constituents of medicinal plants have been considered to be a basic requirement in the discovery of potent medicines and remedies on various diseases in ayurvedic and nutraceutical research. Medicinal properties of any plant are depending on the presence of phytoconstituents and nutritive elements as well as minerals. Medicinal plants are effective against various health problems due to their pharmacological efficacy which is depends on their elemental concentrations [16]. Likewise, phytochemical screening, elemental and functional group analysis of plant extract is also essential to evaluate medicinal properties of
Vitex negundo. Hence present research was designed to evaluate soluble extractive percentage, phytochemical screening, elemental and functional group analysis of Vitex negundo leaves.

\section{MATERIALS AND METHODS}

\section{Chemicals and reagents}

Millions reagent, ninhydrin reagent, benedicts reagent, glacial acetic acid, acetone, tannic acid (Loba), picric acid (Himedia), methanol (Himedia), multi-element standards (Fluka make, USA), sodium nitropruside, ferric chloride (Sigma-Aldrich).

\section{Plant collection and authentication}

Vitex negundo L. was collected from Pune district, Maharashtra (India). The plant has been identified morphologically and authenticated by Senior Scientist D; at Botanical Survey of India (BSI), Pune, Maharashtra (India). Here a voucher specimen no. VMK 04 has been submitted.

\section{Preparation of plant extract}

Shade dried leaves of Vitex negundo were ground by the mechanical grinder and extracted with acetone, methanol and water by maceration process. Concentrated extracts have been used for phytochemical and FTIR spectroscopy analysis.

\section{Determination of extractive value of Vitex negundo L. leaves}

Three solvents i.e. methanolic, aqueous and acetone have been used to find the comparatively higher extractive value of Vitex negundo L. leaves [17].

\section{Phytochemical screening}

Phytochemical screening has been done for detection of carbohydrates, proteins, amino acids, steroids, glycosides, flavonoids, alkaloids, tannins and phenolic compounds $[17,18]$. 


\section{FTIR spectroscopy analysis}

FTIR spectroscopy (Model-Nicoleti S 5) analysis used for determination of herbal functional groups [19].

\section{ICP-MS analysis}

Dry leaves powder of Vitex negundo was analysed for elemental detection which was conducted on ICP-MS technique. ICP-MS is most trusted technique for elemental analysis due to its rapid detection and capability to detect elements in extremely minute concentrations [20].

\section{RESULTS}

Maximum soluble extractive percentage of Vitex negundo leaves was found in the aqueous extract $(6.75 \%)$ followed by methanolic extract $(4.35 \%)$ and less in acetone extract (1.8\%) (Table 1).

Table 1: Percentage value of soluble extractive of Vitex negundo L

\begin{tabular}{lll}
\hline Solvents & Weight of plant material (g) & Soluble extractive percentage (\%) of Vitex negundo L. leaves \\
\hline Aqueous & 2 & 6.75 \\
Methanol & 2 & 4.35 \\
Acetone & 2 & 1.8 \\
\hline
\end{tabular}

Table 2: Phytochemical screening of aqueous, methanolic and acetone extracts of Vitex negundo $\mathrm{L}$

\begin{tabular}{|c|c|c|c|c|c|}
\hline \multirow[t]{2}{*}{ S. No. } & \multirow[t]{2}{*}{ Secondary metabolites } & \multirow[t]{2}{*}{ Phytochemical tests } & \multicolumn{3}{|c|}{ Vitex negundo L. leaves } \\
\hline & & & Methanolic extract & Acetone extract & Aqueous extract \\
\hline 1. & Carbohydrates & Molisch's Test & ++ & ++ & ++ \\
\hline 2. & Proteins & Millon's Reagent Test & ++ & - & ++ \\
\hline 3. & Amino acid & Ninhydrin Test & ++ & - & ++ \\
\hline 4. & Steroid & Liebermann Burchard Reaction & ++ & - & - \\
\hline \multirow[t]{5}{*}{5.} & Glycosides & Legal's Test & - & - & + \\
\hline & a)Cardiac glycosides & & & & \\
\hline & b)Anthraquinone glycosides & Borntrager's Test & ++ & ++ & ++ \\
\hline & c)coumarin glycosides & Fluorescence Test & - & - & - \\
\hline & d)Saponin glycosides & Foam Test & - & - & ++ \\
\hline 6. & Flavonoids & Sodium hydroxide test & - & ++ & + \\
\hline \multirow[t]{2}{*}{7.} & Alkaloids & Mayer's Test & - & - & - \\
\hline & & Hager's Test & - & - & - \\
\hline 8. & Tannins and phenolic compounds & Dilute nitric acid test & ++ & ++ & - \\
\hline
\end{tabular}

“+= Present; -= Absent”

The phytochemical screening of three different extracts of Vitex negundo L. leaves showed the presence of phytochemicals like carbohydrates, proteins, amino acids, saponins, flavonoids, anthraquinones, tannins and phenolic compounds. The results of present study are helpful for the discovery of potent remedies on various diseases. Medicinal plants are main source for potent bioactive compounds. Acetone extract and aqueous extract of Vitex negundo leaves shows the presence of flavonoids, the present study also useful for preparing flavonoid-based drugs which have been most important in antioxidant, antiallergic, antimicrobial properties (table 2).

Table 3: Elemental analysis of Vitex negundo L. leaves by ICP-MS

\begin{tabular}{llll}
\hline & & Vitex negundo L. Leaves & Conc(ppm) \\
\hline Elements & Conc (ppm) & Elements & 3.06 \\
\hline $7 \mathrm{Li}[1]$ & 0.35 & $60 \mathrm{Ni}[1]$ & 8.944 \\
$9 \mathrm{Be} \mathrm{[1]}$ & 0.00 & $63 \mathrm{Cu}[1]$ & 40.489 \\
$11 \mathrm{~B} \mathrm{[1]}$ & 73.6 & $66 \mathrm{Zn} \mathrm{[1]}$ & 0.26 \\
$23 \mathrm{Na}[1]$ & 31.98 & $75 \mathrm{As} \mathrm{[1]}$ & 159.8 \\
$24 \mathrm{Mg}[1]$ & 5663.8 & $82 \mathrm{Se} \mathrm{[1]}$ & 0.268 \\
$27 \mathrm{Al[1]}$ & 876.3 & $95 \mathrm{Mo} \mathrm{[1]}$ & 0.00 \\
$31 \mathrm{P} \mathrm{[1]}$ & 4130.6 & $107 \mathrm{Ag}[1]$ & 0.09 \\
$39 \mathrm{~K} \mathrm{[1]}$ & 2332.4 & $111 \mathrm{Cd}[2]$ & 0.00 \\
$43 \mathrm{Ca}[1]$ & 1566.2 & $118 \mathrm{Sn}[1]$ & 0.00 \\
$52 \mathrm{Cr}[1]$ & 4.16 & $137 \mathrm{Ba}[1]$ & 0.00 \\
$55 \mathrm{Mn}[1]$ & 214.8 & $208 \mathrm{~Pb}[2]$ & 0.12 \\
$56 \mathrm{Fe}[1]$ & 128.1 & $202 \mathrm{Hg}[1]$ & 0.00 \\
$59 \mathrm{Co} \mathrm{[1]}$ & 0.71 & $209 \mathrm{Bi} \mathrm{[1]}$ & \\
\hline
\end{tabular}

Elemental analysis of Vitex negundo leaves by ICP-MS technique has been confirmed the presence of pharmaceutically active major, minor and trace elements. The results of elemental analysis were recorded in table 3 , which revealed presence of $B$ (73.6 ppm), Na (31.98 ppm), Mg (5663.8 ppm), P (4130.6 ppm), K (2332.4 ppm), Ca (1566.2 ppm), Cr (4.16 ppm), Mn (214.8 ppm),
Fe (128.1 ppm), Ni (3.06 ppm), Cu (8.944 ppm), Zn (40.489 ppm), Se (159.8 ppm) and Mo (0.268 ppm). Some heavy metals have been found in trace and higher amount such as Li $(0.35 \mathrm{ppm})$, as (0.26 ppm), Cd (0.09 ppm), Hg (0.12 ppm) and Al (876.3 ppm). Toxic metals like $\mathrm{Be}, \mathrm{Ag}, \mathrm{Sn}, \mathrm{Ba}, \mathrm{Pb}$ and $\mathrm{Bi}$ were found totally absent in Vitex negundo leaves. 


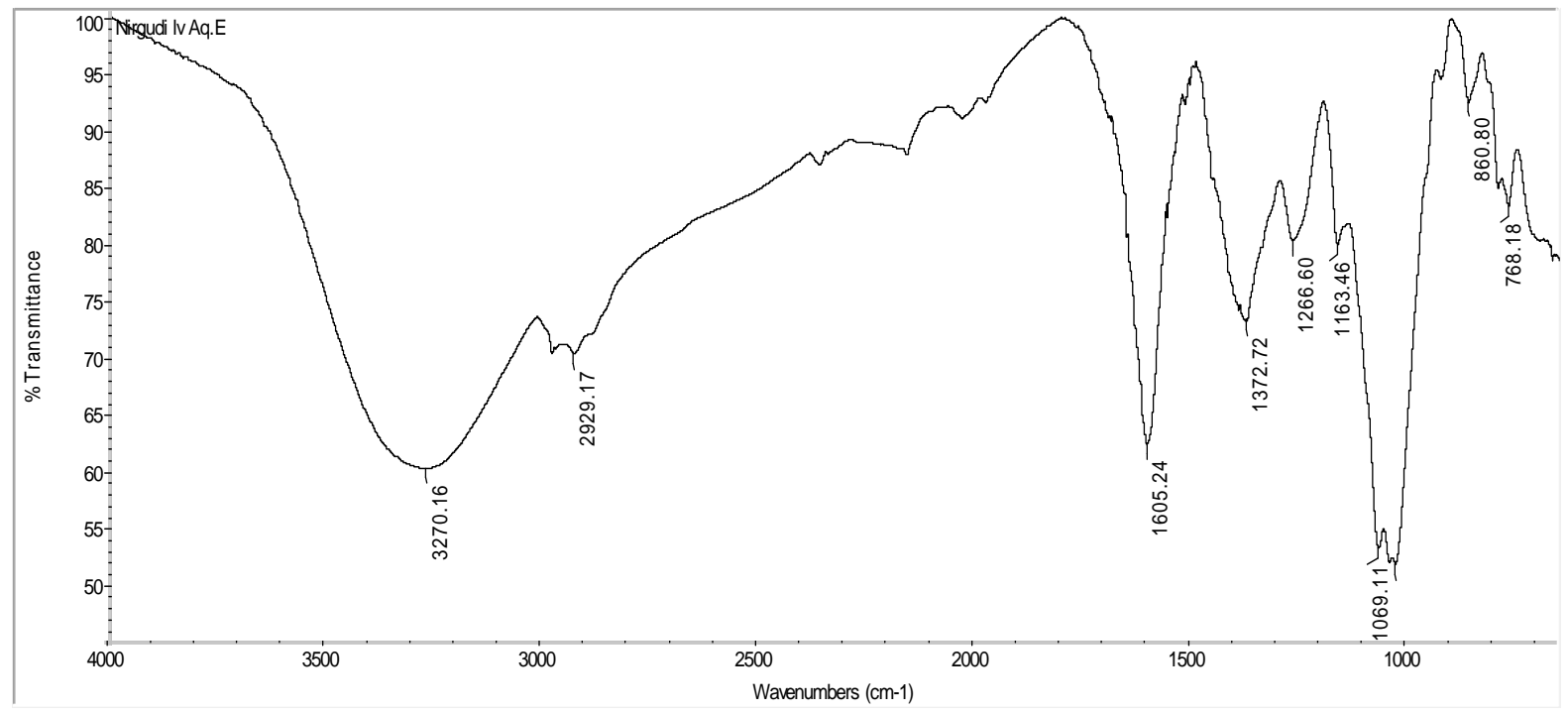

Fig. 1: FTIR spectrum aqueous extract of Vitex negundo leaves

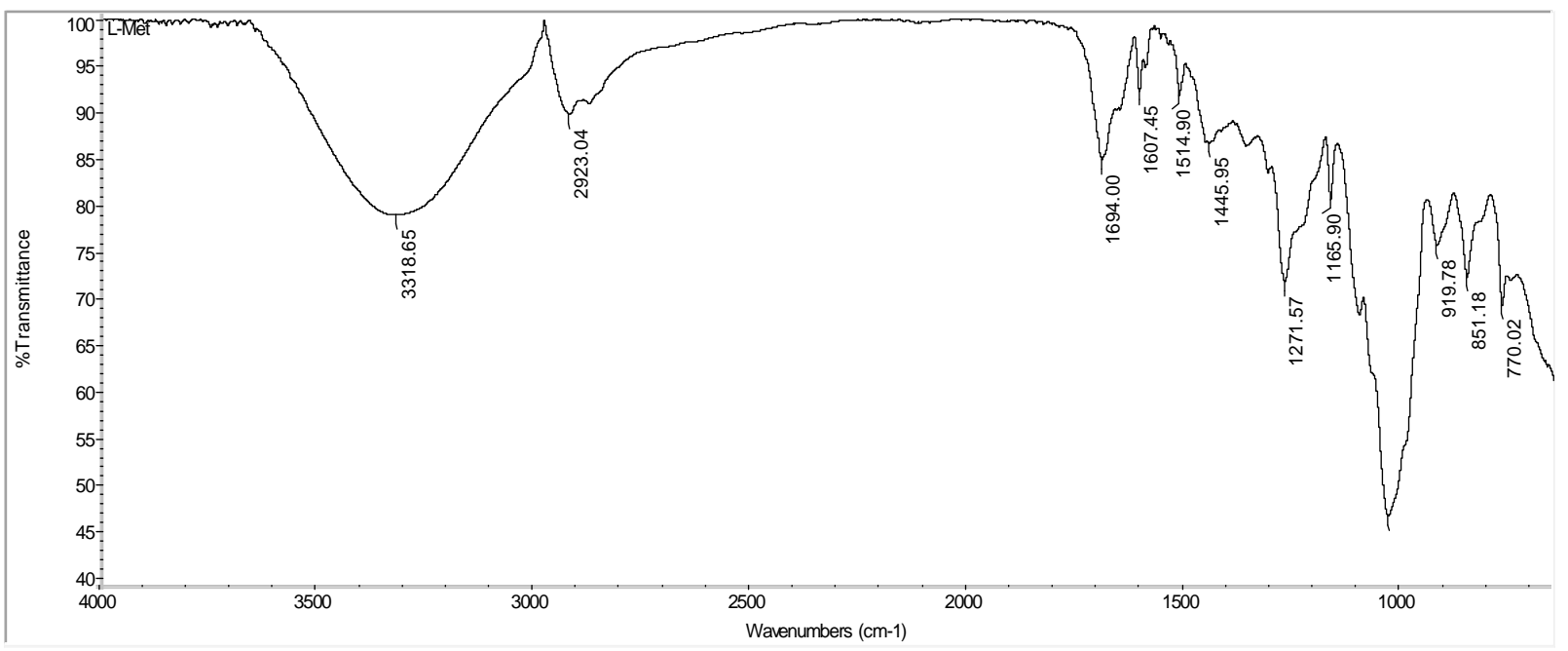

Fig. 2: FTIR spectrum methanolic extract of Vitex negundo leaves

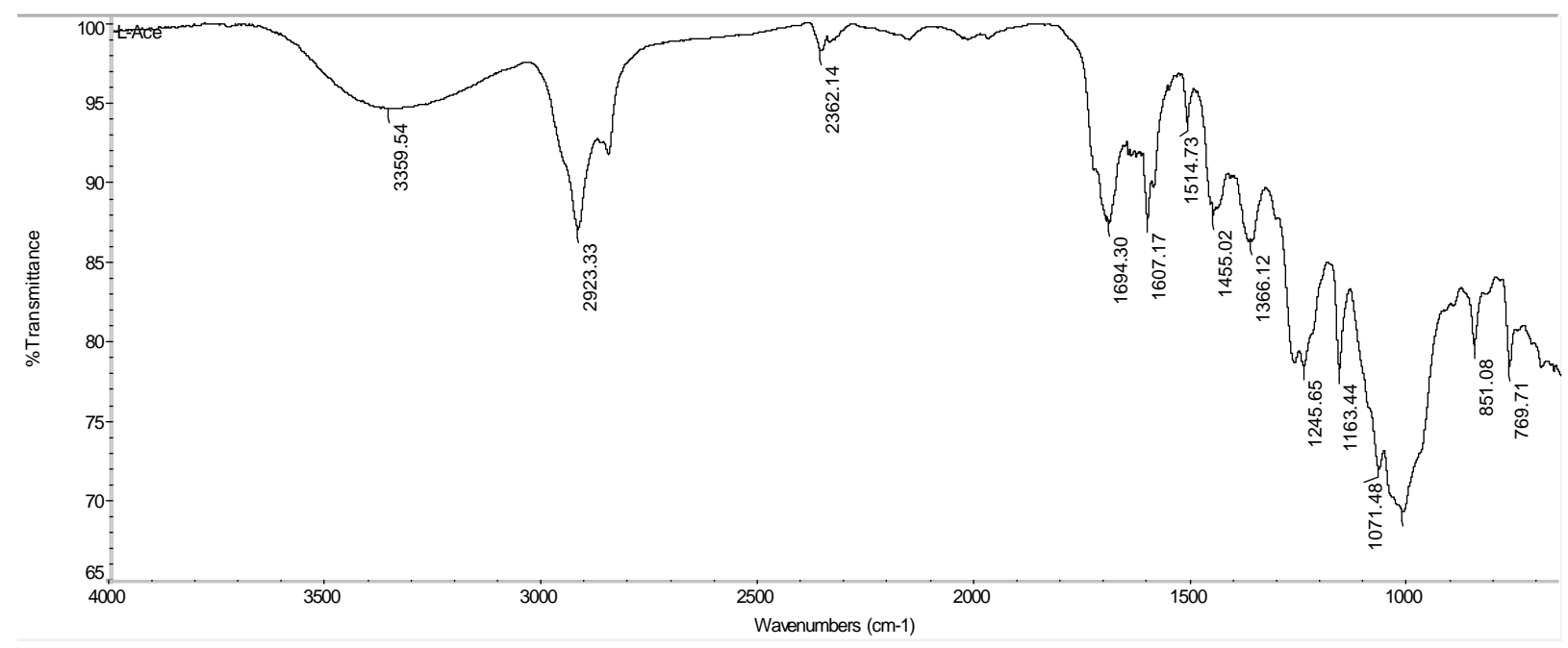

Fig. 3: FTIR spectrum acetone extract of Vitex negundo leaves 
Table 4: Spectra analysis of Vitex negundo L. leaves extracts

\begin{tabular}{|c|c|c|c|c|c|c|}
\hline \multirow{2}{*}{$\begin{array}{l}\text { S. } \\
\text { No. }\end{array}$} & \multirow{2}{*}{$\begin{array}{l}\text { Vitex negundo leaves } \\
\text { functional groups } \\
\text { assignment }\end{array}$} & \multirow[t]{2}{*}{ Component (peaks) } & \multicolumn{4}{|c|}{ Absorption spectrum, frequency $\left(\mathrm{cm}^{-1}\right)$} \\
\hline & & & $\begin{array}{l}\text { Wave number } \mathrm{cm}^{-1} \\
\text { (Reference article) }[21,22]\end{array}$ & $\begin{array}{l}\text { Aqueous } \\
\text { extract }\end{array}$ & $\begin{array}{l}\text { Methanolic } \\
\text { extract }\end{array}$ & $\begin{array}{l}\text { Acetone } \\
\text { extract }\end{array}$ \\
\hline 1 & Hydroxyl Compound & $\begin{array}{l}\text { O-H Stretch } \\
\text { (Strong, Broad) }\end{array}$ & $3200-3400$ & 3270.16 & 3318.65 & 3359.54 \\
\hline 2 & Asymmetric stretching & $\begin{array}{l}\text { C-H vibration (Medium } \\
\text { stretch) }\end{array}$ & $\begin{array}{l}2915-2935 \\
2800-3000\end{array}$ & 2929.17 & 2923.04 & 2923.33 \\
\hline 3 & Ester/Phosphorus function & P-H-stretching (Weak stretch) & $2325-2425$ & -- & -- & 2362.14 \\
\hline 4 & Saturated fatty acid & (Medium stretch) & $1600-1800$ & -- & 1694 & 1694.3 \\
\hline 5 & Amine & N-H (Medium stretch) & $1550-1650$ & 1605.24 & 1607.45 & 1607.17 \\
\hline 6 & Aromatic compounds & $\mathrm{C}=\mathrm{C}($ Weak $/$ medium stretch $)$ & $1400-1600$ & -- & $\begin{array}{l}1514.9 \\
1445.95\end{array}$ & $\begin{array}{l}1514.73 \\
1455.02\end{array}$ \\
\hline 7 & Alkanes & C-H (Medium stretch) & $1350-1480$ & 1372.72 & -- & 1366.12 \\
\hline 8 & $\begin{array}{l}\text { Aromatic compounds } \\
\text { (Oxidized Nitrogen } \\
\text { Function) }\end{array}$ & N-O (Medium stretch) & $1080-1360$ & 1266.6 & -- & -- \\
\hline 9 & $\begin{array}{l}\text { Carboxylic acid and } \\
\text { derivatives }\end{array}$ & $\mathrm{C}=0$ (Strong stretch) & $1210-1320$ & -- & 1271.57 & 1245.65 \\
\hline 10 & Amine & N-H (Medium stretch) & $1080-1360$ & 1163.46 & 1165.9 & 1163.44 \\
\hline 11 & Ether & C-O (Strong stretch) & $1000-1300$ & 1029.44 & 1032.18 & $\begin{array}{l}1071.48 \\
1015.91\end{array}$ \\
\hline 12 & Branched chain Alkanes & C-H (Weak bend) & $919-922$ & -- & 919.78 & -- \\
\hline 13 & $1^{\circ}$ and $2^{\circ}$ Amines & $\begin{array}{l}\mathrm{N}-\mathrm{H} \text { (Medium strech) } \\
\mathrm{C}-\mathrm{N}\end{array}$ & $660-900$ & $\begin{array}{l}860.8 \\
768.18\end{array}$ & $\begin{array}{l}851.18 \\
770.02\end{array}$ & $\begin{array}{l}851.08 \\
769.71\end{array}$ \\
\hline
\end{tabular}

The results of FTIR analysis of Vitex negundo leaves extracts have been recorded in table 4, fig. 1, fig. 2 and fig. 3. The present investigation of FTIR analysis revealed the presence of probable phytoconstituents as per the identified herbal functional groups from the Vitex negundo leaves extracts. Characteristic peaks for hydroxyl compounds $\mathrm{O}-\mathrm{H}$ (Stretch) were obtained in aqueous $\left(3270.16 \mathrm{~cm}^{-1}\right)$, methanolic $\left(3318.65 \mathrm{~cm}^{-1}\right)$ and acetone $(3359.54 \mathrm{~cm}$ ${ }^{1}$ ) extracts. C-H vibrations of asymmetric stretching have been found in aqueous, methanolic and acetone extracts of Vitex negundo leaves such as $2929.17 \mathrm{~cm}^{-1}, 2923.04 \mathrm{~cm}^{-1}$ and $2923.33 \mathrm{~cm}^{-1}$. Ester/Phosphorus function P-H (stretch) was recorded only in acetone extract at $2362.14 \mathrm{~cm}^{-1}$ and functional group for saturated fatty acids was recorded in the methanolic extract at $1694 \mathrm{~cm}^{-1}$ and acetone extract at $1694.3 \mathrm{~cm}^{-1}$. The present study confirms the presence of amines $\mathrm{N}-\mathrm{H}$ (stretch) and $\mathrm{C}-\mathrm{N}$ (stretch) in all extracts but at different characteristic peaks, in aqueous extract at $1605.24 \mathrm{~cm}^{-1}$, $1163.46 \mathrm{~cm}^{-1}, 860.8 \mathrm{~cm}^{-1}, 768.18 \mathrm{~cm}^{-1}$, in methanolic extract at $1607.45 \mathrm{~cm}^{-1}, 1165.9 \mathrm{~cm}^{-1}, 851.18 \mathrm{~cm}^{-1}, 770.02 \mathrm{~cm}^{-1}$ and in acetone extract at $1607.17 \mathrm{~cm}^{-1}, 1163.44 \mathrm{~cm}^{-1}, 851.08 \mathrm{~cm}^{-1}, 769.71 \mathrm{~cm}^{-1}$. Aromatic compounds $\mathrm{C}=\mathrm{C}$ (stretch) and oxidized nitrogen function aromatic compounds N-O (stretch) have been recorded at 1514.9 $\mathrm{cm}^{-1}, 1445.95 \mathrm{~cm}^{-1}$ in methanolic extract, at $1514.73 \mathrm{~cm}^{-1}, 1455.02$ $\mathrm{cm}^{-1}$ in acetone extract and at $1266.6 \mathrm{~cm}^{-1}$ in aqueous extract. Alkanes and branched chain alkanes were found in the aqueous extract at $1372.72 \mathrm{~cm}^{-1}$, in acetone extract $1366.12 \mathrm{~cm}^{-1}$ and in the methanolic extract at $919.78 \mathrm{~cm}^{-1}$. The characteristic peaks detected at $1271.57 \mathrm{~cm}^{-1}$ for methanol extract and $1245.65 \mathrm{~cm}^{-1}$ for acetone extract is assigned to Carboxylic acid and derivatives $\mathrm{C}=0$ (stretch). Ether C-O (stretch) has been obtained in all extracts at $1029.44 \mathrm{~cm}^{-1}$ in aqueous extract, at $1032.18 \mathrm{~cm}^{-1}$ in methanolic extracts and at $1071.48 \mathrm{~cm}^{-1}, 1015.91 \mathrm{~cm}^{-1}$ in acetone extract.

\section{DISCUSSION}

Vitex negundo has been traditionally used in ayurvedic medicine to treat several disorders such as catarrh, headache, neck gland sores, tubercular neck swellings, sinusitis, sexual debilities, nervous debility, liver complaints, inflammation of uterus, fever, diarrhoea etc [23]. The result of present research important to proves the medicinal properties of Vitex negundo. N. Nirmalkumar (2014) was reported aqueous soluble extractive value $22.45 \%$ and alcoholic soluble extractive value $5.99 \%$ which indicated the maximum extractive percentage found in water extract [24] and as per the present investigation similar results have been reported, maximum extractive value has been found in aqueous extracts than methanolic and acetone extract. The phytochemical screening of Vitex negundo leaves extracts revealed the presence of carbohydrates, proteins, amino acids, steroids, glycosides (cardiac, anthraquinone and saponin), flavonoids, tannins and phenolic compounds. The presence of these primary and secondary metabolites suggests that the Vitex negundo have curative ability against several diseases. Hence present results might be important to support the ethanomedicinal and traditional medicinal properties of Vitex negundo. Presence of tannins and phenolic compounds proves that plants may be having antiviral, antibacterial and wound healing activity [25]. Ramesh Mani et. al (2013) was revealed the presence of alkaloids, carbohydrates, cardiac glycosides, flavonoids, glycosides, phenols, proteins, saponin and tannins in methanolic extract of Vitex negundo leaves [26]. The present study also recorded same phytochemicals and also reported streroids in methanolic extract of Vitex negundo leaves.

The ICP-MS analysis study revealed the presence of major elements like $\mathrm{Ca}, \mathrm{Mg}, \mathrm{Na}, \mathrm{K}$ and $\mathrm{P}$ have been found in maximum concentrations which are the quantity elements. Micro/trace elements such as $\mathrm{Cr}$, $\mathrm{Mn}, \mathrm{Fe}, \mathrm{Co}, \mathrm{Ni}, \mathrm{Cu}, \mathrm{Zn}$, Se and Mo were quantified in sufficient concentrations. According to frieden (1985) Boron, Cobalt, Copper, Iodine, Iron, Mangenese, Molybdenum and Zinc are biologically essential elements whereas chromium, nickel, selenium are probable biologically essential elements [27].

The FTIR analysis study has confirmed the presence of vital functional groups which may be important in the synthesis of pharmaceutically active phytoconstituents. Detection of hydroxyl groups is an indication of presence of flavonoids, alcoholic and phenolic compounds [28]. Vitex negundo is an aromatic plant which is confirmed in present research by detection of aromatic functional groups and oxidized nitrogen functional aromatic groups. The occurrence of alkaloids in Vitex negundo leaves extracts confirmed by the presence of alkanes, amines, primary and secondary amines and aromatic compounds [29]. Some lipids and proteins have assymmetric streching due to $\mathrm{C}-\mathrm{H}$ vibration and saturated fatty acids, which were detected in the present research. Many organic acids contain carboxylic acids and their derivatives and which are responsible for several medicinal properties.

\section{CONCLUSION}

The results of present study are helpful for the discovery of potent remedies on various diseases. Medicinal plants are main source for potent bioactive compounds. The phytochemical screening using three different material extracts showed the presence of the primary and secondary metabolites in aqueous and methanolic extract than 
acetone extract. The phytochemical screening of three different extracts of Vitex negundo L. leaves showed the presence of phytochemicals like carbohydrates, proteins, amino acids, saponins, flavonoids, anthraquinones, tannins and phenolic compounds. Acetone extract and aqueous extract of Vitex negundo leaves shows the presence of flavonoids, the present study also useful for preparing flavonoid-based drugs which have been most important in antioxidant, antiallergic, antimicrobial properties. The soluble extractive value was found the maximum in aqueous extract hence aqueous extract is most effective for studying the pharmacological activity of this plant. Elemental analysis showed the presence of trace elements in sufficient concentrations and traces of heavy and toxic metals. The FTIR study revealed the presence of essential functional groups in three different extracts of the material. Present investigation is most essential to discover innovative, dynamic and novel drugs for curing various newly emerged dangerous diseases.

\section{ACKNOWLEDGEMENT}

The authors are grateful to UGC for financial support and Hon. Prof. Shivajirao Kadam (Vice Chancellor), Prin. Dr. K. D. Jadhav for encouragement and facilities provided during present investigation.

\section{AUTHOR CONTRIBUTION}

These authors contributed equally to this work

\section{CONFLICT OF INTERESTS}

There is no conflict of interest between both the authors of this work

\section{REFERENCES}

1. Morabad RB, Patil SJ. Elemental profile analysis of some Indian traditional medicinal spice seeds of Ballari district, Karanataka using AAS technique. Int J Curr Pharm Res 2017;9:56-61.

2. Vishwanathan AS, Basavaraju. A review on Vitex negundo L.-A medicinally important plant. Eur J Biol Sci 2010;3:30-42.

3. Samy PR, Ignacimuthu S, Sen A. Screening of 34 Indian medicinal plants for antibacterial properties. J Ethnopharmacol 1998;62:173-82.

4. Sahayaraj K. Antifeedant effect of some plant extracts on the Asian armyworm, Spodoptera litura (Fabricius). Curr Sci 1998;74:523.

5. Guleria S, Kumar A. Antifungal activity of some Himalayan medicinal plants using direct bioautography. J Cell Mol Biol 2006;5:95-8.

6. Nathan SS, Kalaivani K, Murugan K. Behavioral responses and changes in the biology of rice leaf folder following treatment with a combination of bacterial toxins and botanical insecticides. Chemosphere 2006;64:1650-8.

7. Das GP. Plants used in controlling the potato tuber moth, Phthorimaea operculella (Zeller). Crop Prot 1995;14:631-6.

8. Hebbalkar DS, Hebbalkar GD, Sharma RN, Joshi VS, Bhat VS. Mosquito repellent activity of oils from Vitex negundo Linn leaves. Indian J Med Res 1992;95:200-3.

9. Gupta RK, Tondon VR. Antinociceptive activity of Vitex negundo Linn leaf extract, proceedings of $35^{\text {th }}$ annual Conference of Indian Pharmacological Society. Gwalior (Abstract). Indian J Pharmacol 2004;36:54.

10. Tondon VR, Gupta RK. Histomorphological changes induced by Vitex negundo in albino rats. Indian J Pharmacol 2004;36:176-7.

11. Dharmasiri MG, Jayakody JR, Galhena G, Liyanage SS, Ratnasooriya WD. Anti-inflammatory and analgesic activities of mature fresh leaves of Vitex negundo. J Ethanopharmacol 2003;87:199-206.

12. Gupta RK, Tondon VR. An experimental evaluation of anticonvulsant activity of Vitex negundo. Proceedings of $48^{\text {th }}$ Annual Conference, Dec-17-20, 2002 in CME programme in physiology and pharmacology, Lucknow (Abstract). Indian J Physiol Pharmacol 2002;46:82.

13. Munasinghe TCJ, Senevirathe CK, Thabrew MI, Abeysekera AM. Antiradical and antilipoperoxidative effect of some plant extracts used by Shri Lankan traditional medicinal practitioner for cardioprotection. Phytother Res 2001;15:519-23.

14. Tondon VR, Gupta RK. Effect of Vitex negundo on oxidative stress. Indian J Pharmacol 2005;37:38-40.

15. Chaudhary RD. Herbal Drug Industry. A practical approach to industrial pharmacognosy. $1^{\text {st }}$ Edn. (Eastern Publisher, New Delhi); 1996. p. 467.

16. Pawar SG, Kamble VM. Elemental analysis of anti-allergenic indigenous plants and their possible correlation with therapeutic activity. Int J Pharm Chem Res 2016;8:1290-5.

17. Khandelwal KR. Practical pharmacognosy, technique and experiments. Ninth Edition. Nirali Prakashan; 2002. p. 23, 10 $23,11,25,1-25,6$.

18. Harborn. Phytochemical methods a guide to modern techniques of plant analysis. Third edition. Chapman and Hall Publisher; 1998.

19. Joshi DD. FTIR-spectroscopy: herbal drugs and fingerprints, ebook: Springer India Publisher; 2012. p. 121-46.

20. Queralt I, Ovejero M, Carvalho ML, Marques AF, Liabres JM. Quantitative determination of essential and trace element content of medicinal plants and their infusions by XRF and ICP technique. X-Ray Spectrum 2005;34:213-7.

21. Silverstein RM, Bassler GC, Morrill TC. Spectrometric identification of organic compounds. $4^{\text {th }}$ ed. New York, John Wiley and Sons; 1981.

22. William Reusch. Infrared spectroscopy. Available from: www.chemistry.msu.edu. [Last accessed on 10 May 2013]

23. Ladda Pl, Magdum CS. Vitex negundo Linn: ethanobotany, phytochemistry and pharmacology-a review. Int J Adv Pharm Biol Chem 2014;1:111-20.

24. Nirmalkumar N. Pharmacognostic and phytochemical analysis of Vitex negundo L. Int J Innov Res Sci Eng Tech 2014;3:14501-5.

25. Haslem E. Plant polyphenols: vegetable tannins revisitedChemistry and pharmacology of natural products. Cambridge University Press: Cambridge; 1989. p. 169.

26. Mani R, Arumugam M, Lakshmanan K. Phytochemical Screening and antibiogram property of methanol extract of Vitex negundo L. Int J Drug Formulation Res 2013;4:76-85.

27. Frieden E. New perspectives on the essential trace elements. J Chem Educ 1985;62:917-23.

28. Kumar S, Panday AK. Review article, chemistry and biological activities of flavonoids: an overview. Sci World J 2013;1-17. http://dx.doi.org/10.1155/2013/162750

29. Corlett S. Organic Chemistry, Chem 12 A/B, Alkaloids functional group worksheet. Available from: www.laney.edu> corlett [Last accessed on 10 Jan 2012]

\section{How to cite this article}

- Sunil Pawar, Vanita Kamble. Phytochemical screening, elemental and functional group analysis of Vitex negundo L. leaves. Int J Pharm Pharm Sci 2017;9(6):226-230. 